\title{
Decision Support System for Determining Thesis Supervisor using A Weighted Product (WP) Method
}

\author{
Suci Ramadhani Arifin ${ }^{1}$, Josua Crishan Mintamanis ${ }^{2}$ \\ 1,2 English Department Tadulako University, Palu Sulawesi Tengah, Indonesia \\ ${ }^{1,2}$ scrmd88@gmail.com, crishanjoshua116@gmail.com
}

\begin{abstract}
English Department of Tadulako University is a department with the highest number of lecturers in Tadulako University. Thesis supervisor determination at the English Department of Tadulako University still use the conventional way so that the determination of the thesis supervisor is done in a long time. In addition, some lecturers have more workload than other lecturers. Decision support system for the determination of the thesis supervisor in the English Department of Tadulako University was built to overcome this problem using the Weighted Product method. The system is a desktop-based application using the Visual Studio programming language and MySQL DBMS for database processing. The application of a decision support system for determining thesis supervisors can help make the selection of supervisors accurately and quickly with a mathematical calculation system.
\end{abstract}

Keywords- Thesis Supervisor, Decision Support System, Weighted Product Method

\section{INTRODUCTION}

The Thesis is the final subject that must be completed by undergraduate students to get a bachelor's degree. In the process of making up to the completion stage, students will receive guidance and direction and input from the lecturer appointed as a student supervisor.

Faculty of Education and Teacher Training Tadulako University consists of fifteen undergraduate departments including the English Department. The English Department is a department with the highest number of lecturers in Tadulako University.

The determination of the thesis supervisor in the English Department at Tadulako University is currently using the conventional method, which is done by determining directly by considering the suitability between education, functional and competency of the prospective lecturer with the title of the thesis submitted by the student.

The problem then arises because the English Department of Tadulako University requires a considerable amount of time in determining the thesis supervisor so that the thesis title is submitted by students suitable to the lecturer competency criteria. The determination of the thesis supervisor directly also resulted in some lecturers having more workload than other lecturers.

To overcome these problems, a decision support system is needed to determine the thesis supervisor in the English Department at Tadulako University. The application of a decision support system to determine thesis supervisors can help in selecting the supervisor properly and quickly with a mathematical calculation system. In this research, ten criteria were set to become a reference in the process of determining a thesis supervisor. These criteria consist of: (1) Appropriate teaching topics, (2) Assistance schedule, (3)
Direction, (4) English communication, (5) Willing to help with references technique, (6) Attention, (7) Consequence, (8) Duration of assistance, (9) Relationship with the work team, (10) Easy grader.

Many researches have been done for determining thesis supervisor with decision support system. Ruskan [1] analyze and produce a decision support system for determining thesis supervisor according to the predetermined criteria; education background, teaching history, research history, interest and functional. Decision Support System Development Method using AHP (Analitycal hierarchical process). Ruskan research produces a system that can recommend thesis supervisor according to the student's final assignment title and the criteria of the lecturer and student. So that the communication process in guiding students and lecturers can run smoothly and the results of the final assignment are more qualified.

Cahyono and Thamrin [2] also conducted a study to determine thesis supervisors for students in the informatics department at Muhammadiyah University of Surakarta using the AHP (Analytical Hierarchical Process) method. Cahyono and Thamrin [2] then concluded that the application made it easier for the informatics department to select thesis supervisors with application accuracy of $53.8 \%$.

Asrul Khairul Umam [3] designed decision support system application to determine thesis supervisor in the informatics department of UIN Sunan Gunung Djati Bandung. The determination is based on the criteria of the lecturer expertise field by applying the fuzzy method. The results of Asrul Khairul Umam's research [3] produced thesis supervisors according to student theses and made it 
easier to determine the thesis supervisor according to the criteria of lecturer expertise.

Laengge et al. [4] built a decision support system to determine thesis supervisors to help the informatics department at Sam Ratulangi University in determining the thesis supervisor using the Simple Additive Weighting (SAW) method. The test results on the system indicate that the system is able to provide advisory recommendations to users based on calculations performed using the Simple Additive Weighting (SAW) method. In addition, the system also provides features for selecting thesis supervisors.

Septiana et al. [5] developed a decision support system that could provide recommendations to examiners and supervisors in the informatics department of UIN SGD Bandung using the FMADM (Fuzzy Multiple Attribute Decision Making) methods to select the best alternative from a number of predetermined alternatives using the Simple Additive Weighting (SAW) method. The system shows the final results that are expected to be able to determine the recommendation of the examiner lecturer and supervisor optimally according to the specifications of the examiner and the supervisor.

The research was carried out to build a decision support system for determining supervisors in the English department at Tadulako University. The difference in research lies in the method used. In this study, the authors used the Weighted Product (WP) method.

Weighted Product (WP) method is one of the decisionmaking system methods were making a decision can be done more quickly and precisely, according to the desired criteria. The application of the Weighted Product (WP) method is also more efficient because the time needed in the calculation is shorter [6].

\section{METHOD}

The type of this research is qualitative descriptive research. Qualitative descriptive research is a research procedure that produces descriptive data in the form of written or oral words from people and observed actors, directed from a holistic background without isolating individuals and their organizations in variables but looking at them as part of a wholeness [7].

Data collection research is carried out by the method of observation and interviews. Observation method as a data collection tool is an observation activity (sensory) that is planned, systematic, and the results are recorded and interpreted in order to gain an understanding of the subject being observed [8]. Observations carried out by visiting the English Department of Tadulako University directly. The Interview is a face-to-face conversation between the interviewer with a source of information, where the interviewer asked directly about the object and have already been designed [9]. In this research, interviews were conducted with the operators and coordinators of the English Department of Tadulako University.

The method used is the Weighted Product (WP) method. The Weighted Product (WP) method is part of the MultiCriteria Decision Making (MCDM) concept, a decisionmaking technique from several alternative choices available. This method evaluates several alternatives to a set of attributes or criteria, where each attribute does not depend on each other [10]. By using the Weighted Product (WP) method, a decision support system application is developed to determine the thesis supervisor that can be used by the English Department of Tadulako University, which will be an alternative choice and assign weight values to alternative comparisons and criteria.

The steps for solving a problem using the Weighted Product (WP) method are as follows [10], [11].

1. Determine the criteria $(C J)$ which will be used as a reference in decision making. The following are the criteria that will be the reference for assessment in this research.

Table 1. Criteria $(C j)$

\begin{tabular}{ll}
\hline \multicolumn{1}{c}{ Criteria $\left(\boldsymbol{C}_{\boldsymbol{j}}\right)$} \\
\hline $\mathrm{C} 1$ & Appropiate Topic \\
\hline $\mathrm{C} 2$ & Discussion Schedule \\
\hline $\mathrm{C} 3$ & Advice \\
\hline $\mathrm{C} 4$ & English Conversation \\
\hline $\mathrm{C} 5$ & Reference Manager \\
\hline $\mathrm{C} 6$ & Attention \\
\hline $\mathrm{C} 7$ & Consequent \\
\hline C8 & Discussion Duration \\
\hline $\mathrm{C} 9$ & Team Work Relationship \\
\hline $\mathrm{C} 10$ & Easy Grader \\
\hline
\end{tabular}

2. Determine the suitability rating of each alternative on the criteria. Rating matches each alternative on each criterion assessed by 1 to 5 as shown in Table 2 .

Table 2. Suitability Rating

\begin{tabular}{ll}
\hline \multicolumn{2}{c}{ Suitable Rating } \\
\hline 1 & Very Less \\
\hline 2 & Less \\
\hline 3 & Enough \\
\hline 4 & Good \\
\hline 5 & Very Good \\
\hline
\end{tabular}

3. Determine the weight of each criterion's preference. Decision makers give preference weights as follows.

Table 3. Preference Weights

\begin{tabular}{lll}
\hline \multicolumn{3}{c}{ Preference Weight of Each Criteria } \\
\hline C1 & Appropiate Topic & 5 \\
\hline C2 & Discussion Schedule & 3 \\
\hline C3 & Advice & 4 \\
\hline C4 & English Conversation & 5 \\
\hline C5 & Reference Manager & 5 \\
\hline C6 & Attention & 3 \\
\hline C7 & Consequent & 4 \\
\hline C8 & Discussion Duration & 5 \\
\hline C9 & Team Work Relationship & 3 \\
\hline C10 & Easy Grader & 5 \\
\hline
\end{tabular}

4. Multiplying all attributes for an alternative with weights as positive ranks for profit attributes and negative rank weights for cost attributes. The formula for calculating preference values for alternative $A_{i}$, is as follows.

$$
S_{i}=\prod_{j=1}^{n} X_{i j^{w j}}(10)
$$


Where:

$\mathrm{S}$ : express alternative preferences analogous

to vector $\mathrm{s}$

$\mathrm{x} \quad: \quad$ stated value criteria

w : stated weight criteria

i : stated alternative

j : stated criteria

$\mathrm{n} \quad$ : state the number of criteria

But beforehand, we must first improve the weight determined by the formula.

$$
W j=\frac{w j}{\Sigma w j}(10)
$$

The solution method is as follows.

$$
\begin{aligned}
W 1 & =\frac{5}{5+3+4+5+5+3+4+5+3+5}=0,1190 \\
W 2 & =\frac{3}{5+3+4+5+5+3+4+5+3+5}=0,0714 \\
W 3 & =\frac{4}{5+3+4+5+5+3+4+5+3+5}=0,0952 \\
W 4 & =\frac{5}{5+3+4+5+5+3+4+5+3+5}=0,1190 \\
W 5 & =\frac{5}{5+3+4+5+5+3+4+5+3+5}=0,1190 \\
W 6 & =\frac{3}{5+3+4+5+5+3+4+5+3+5}=0,0714 \\
W 7 & =\frac{4}{5+3+4+5+5+3+4+5+3+5}=0,0952 \\
W 8 & =\frac{5}{5+3+4+5+5+3+4+5+3+5}=0,1190 \\
W 9 & =\frac{3}{5+3+4+5+5+3+4+5+3+5}=0,0714 \\
W 10 & =\frac{5}{5+3+4+5+5+3+4+5+3+5}=0,1190
\end{aligned}
$$

After doing weight repairs, vector values are calculated (Si).

Table 4. Alternative Values and Criteria

\begin{tabular}{ccccccccccc}
\hline Dosen & \multicolumn{10}{c}{ Nilai Kriteria } \\
\cline { 2 - 12 } & $C 1$ & $C 2$ & $C 3$ & $C 4$ & $C 5$ & $C 6$ & $C 7$ & $C 8$ & $C 9$ & $C 10$ \\
\hline A & 5 & 4 & 3 & 5 & 5 & 4 & 3 & 4 & 3 & 5 \\
B & 4 & 4 & 4 & 4 & 4 & 4 & 4 & 5 & 3 & 4 \\
C & 5 & 5 & 5 & 5 & 5 & 5 & 5 & 5 & 5 & 5
\end{tabular}

The solution method is as follows.

$S_{1}=\left(5^{0,1190}\right)\left(4^{0,0714}\right)\left(3^{0,0952}\right)\left(5^{0,1190}\right)\left(5^{0,1190}\right)\left(4^{0,0714}\right)\left(3^{0,0952}\right)\left(4^{0,0714}\right)\left(3^{0,0952}\right)\left(5^{0,1190}\right)$ $=4,1232$

$S_{2}$

$\stackrel{S_{2}}{=}\left(4^{0,0714}\right)\left(4^{0,0714}\right)\left(4^{0,0714}\right)\left(4^{0,0714}\right)\left(4^{0,0714}\right)\left(4^{0,0714}\right)\left(4^{0,0714}\right)\left(5^{0,1190}\right)\left(3^{0,0952}\right)\left(4^{0,0714}\right)$ $=4,0219$

$S_{3}$

$S_{3}$
$=$
$\left.=4,5^{0,1190}\right)\left(5^{0,1190}\right)\left(5^{0,1190}\right)\left(5^{0,1190}\right)\left(5^{0,1190}\right)\left(5^{0,1190}\right)\left(5^{0,1190}\right)\left(5^{0,1190}\right)\left(5^{0,1190}\right)\left(5^{0,1190}\right)$

5. The multiplication results are added to produce vector $\mathrm{V}$ values for each alternative. The value of vector $\mathrm{V}$ can be calculated using the formula.

$$
V i=\frac{\prod_{j}^{n}=1^{x i j^{w j}}}{\prod_{j}^{n}\left(X_{j}\right) w_{j}}(10)
$$

Keterangan:
$\mathrm{V}:$ express alternative preferences analogous to vector $\mathrm{V}$
$\mathrm{x}$ : stated value criteria
w : stated weight criteria

i : stated alternative

j : stated criteria

$\mathrm{n}$ : state the number of criteria

The solution method is as follows.

$$
\begin{aligned}
& V_{1}=\frac{4,1232}{4,1232+4,0219+4,9968}=0,3137 \\
& V_{2}=\frac{4,0219}{4,1232+4,0219+4,9968}=0,3060 \\
& V_{3}=\frac{4,9968}{4,1232+4,0219+4,9968}=0,3802
\end{aligned}
$$

6. Looking for an alternative value by performing the same steps as step one, only use the highest grades for each of the highest attributes, for each attribute benefits and the lowest value for the cost attribute.

7. Divide the V-value for each alternative with a standard value.

8. Looking for the ideal alternative grades to rank the value of the vector $\mathrm{V}$ and make a conclusion as the final stage.

Table 5. Results Ranking Thesis Supervisor

\begin{tabular}{cc}
\hline Alternatif & Hasil \\
\hline C & 0,3802 \\
\hline A & 0,3137 \\
\hline B & 0,3060 \\
\hline
\end{tabular}

After all, steps are taken, then find the greatest value, because based on calculations with the Weighted Product (WP) method the best value is the greatest value of all alternatives. From the results of the calculation above, it produces a rating for prospective thesis supervisors from the highest to the lowest. Where the highest three values from above will be used as thesis supervisors in the English Department at Tadulako University.

\section{RESULT AND DISCUSSION}

Implementation of the Weighted Product (WP) method in software in the form of information systems is shown in Figure 1 to Figure 12.

This information system is used to carry out the data collection of student thesis titles as well as the determination of a proper supervisor and match the title that has been submitted by the student without conducting a manual inspection process which will take a long time in determining the final assignment supervisor. The functions that can be performed in this system are data collection of lecturer, lecturer expertise data, assessment of each lecturer criteria, data collection of student thesis titles, determination of supervisors according to the student's thesis title by using the weighted product method which will rank the three lecturers that best match the title submitted, change of supervisor if there is an unexpected case, the judicial verification will function to record how much each lecturer has done in assistance related to the remuneration of lecturer benefits. The following is a display of the information system created. 


\section{A. Login Interface}

The login page will be displayed first before the user uses the system. This page can only be accessed by the admin so that not all people can access the system in processing data related to thesis assistance. The results of the login page implementation can be seen in Figure 1.

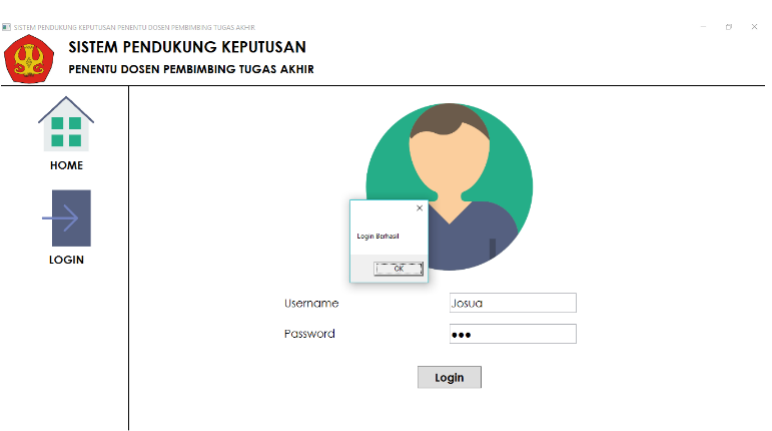

Figure 1. Login Page

\section{B. Lecturer Data Interface}

This page is used to enter lecturers' personal data along with information as main supervisor or companion supervisor. This data will function in the process of determining the supervisor because there are several lecturers who cannot be main supervisor but only as examiners. The results of the implementation of lecturer data pages can be seen in Figure 2.

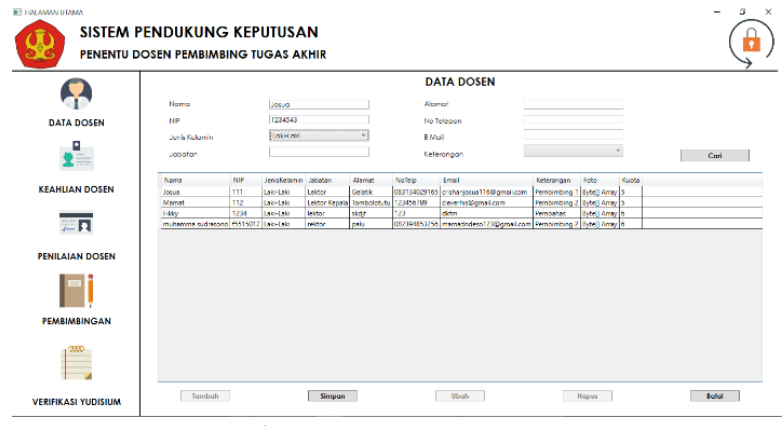

Figure 2. Lecturer Data Page

\section{Lecturer Expertise Interface}

On this page, the lecturer expertise data is filled in, where each lecturer who teaches in the English Department has skills that will later be used as a measure parameter for determining the lecturer related to the title submitted by each student, each student also determines the expertise to be focused on the student's final assignment. The results of the implementation page of lecturer expertise data can be seen in Figure 3.

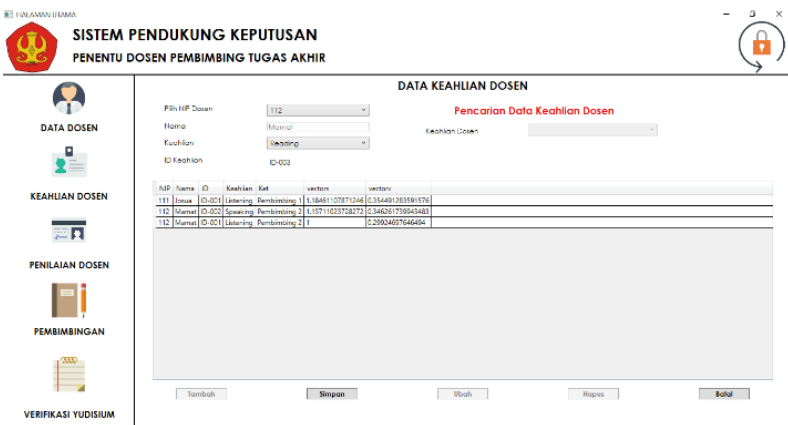

Figure 3. Lecturer Expertise Page

D. Lecturer Skills Assessment

This page serves to assess or weight each lecturer skill based on predetermined criteria. Assessment criteria consist of (1) Appropriate teaching topics, (2) Assistance schedule, (3) Direction, (4) English communication, (5) Willing to help with references technique, (6) Attention, (7) Consequence, (8) Duration of assistance, (9) Relationship with the work team, (10) Easy grader. The results of the implementation of the page assessment of lecturer expertise can be seen in Figure 4.

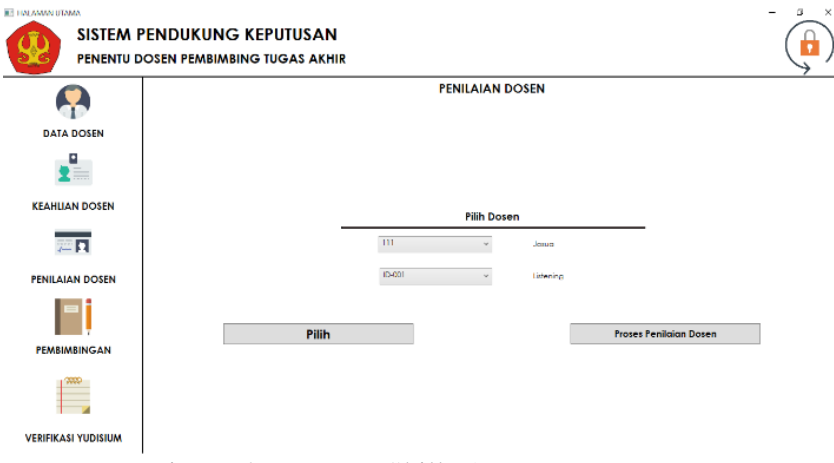

Figure 4. Lecturer Skills Assessment Page

\section{E. Filling Lecturer Skills Interface}

This page serves to provide an assessment of predetermined assessment criteria. Assessment consists of very good, good, enough, less and less good. This assessment becomes the initial weighting that will be used in the weighted product method. So that this assessment process must be carried out in a real and directly assessed based on these criteria. The results of the implementation of the filling lecturer skills page can be seen in Figure 5.

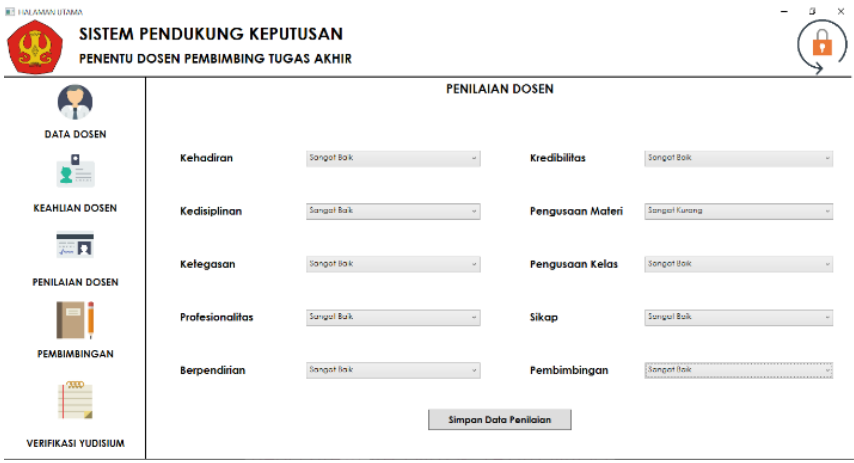

Figure 5. Filling Lecturer Skills Page 
F. Weighted Product (WP) Processing Page Interface On this page, the ranking process for each lecturer is based on a predetermined weighting. The method used is a weighted product method that works by emphasizing each method process on the weighting of each predetermined attribute or criterion to get the best lecturer ranking based on that weight. The results of the Weighted Product (WP) processing page can be seen in Figure 6.

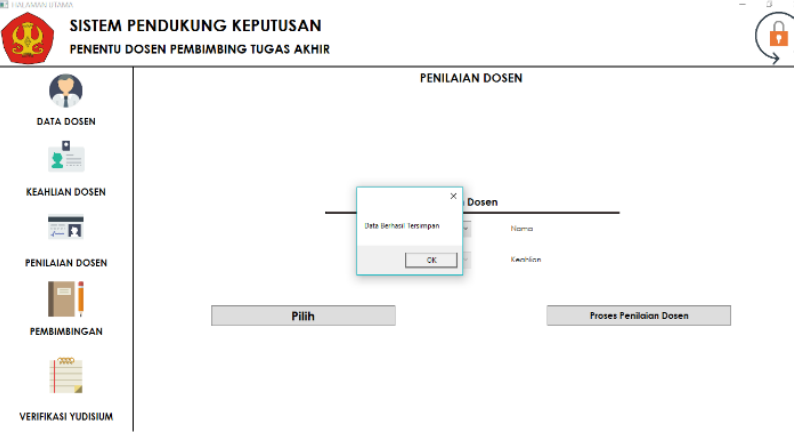

Figure 6. Weighted Product (WP) Processing Page

\section{G. Student Data Interface}

This page is used to input student thesis title data along with the title approval statement letter by the study program coordinator and it has been examined that previously no student has submitted the title. Then on this page the title keyword input is done or the focus of expertise is to filter the assessment of each lecturer based on the expertise in accordance with the title that has been submitted. The results of the implementation of the student data page can be seen in Figure 7.

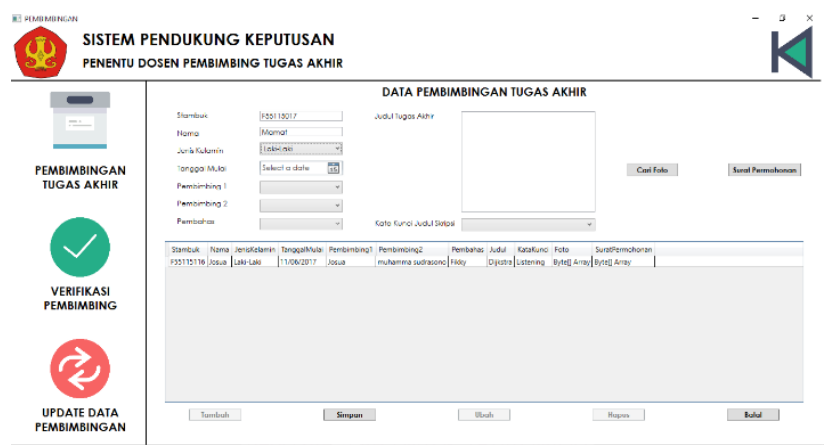

Figure 7. Student Data Page

H. Supervisor Verification Interface

This page is used to select the results of the weighted product method to determine the best supervisor in accordance with the title of the thesis that has been submitted. Lecturer ranking data is displayed in the form of a diagram to see the percentage of the lecturer's value. The results of the implementation of the supervisor verification page can be seen in Figure 8 .

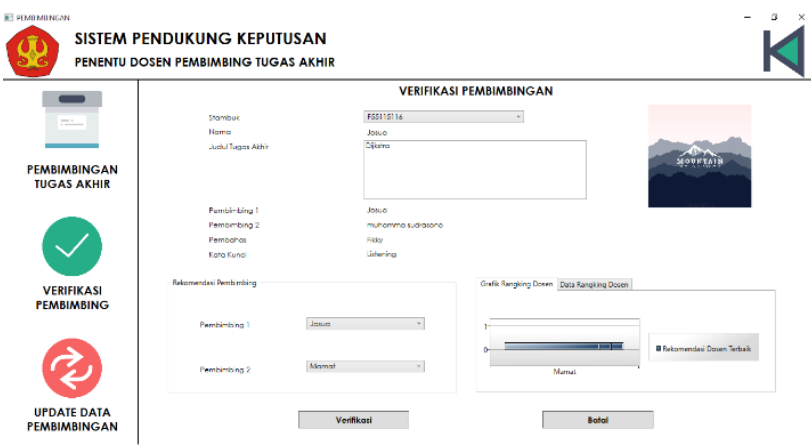

Figure 8. Supervisor Verification Page

I. Data Update Main Page Interface

This page is an intermediary for making changes to mentoring data related to the problem of mentoring several lecturers and to prevent the length of the process of mentoring a student. The results of the implementation of data update main page can be seen in Figure 9.

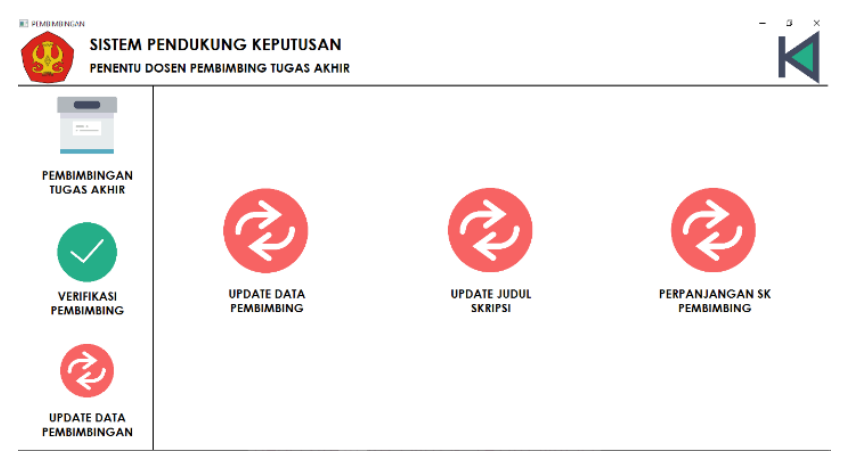

Figure 9. Data Update Main Page

\section{J. Supervisor Data Update Interface}

This page is used to make changes to main or companion supervisor or caused by the coaching process both from the lecturer and from the student. The amended data must first obtain permission from the department coordinator with proof of the supervisor's change statement which will also be included in the system. The results of the implementation of the supervisor data update page can be seen in Figure 10.

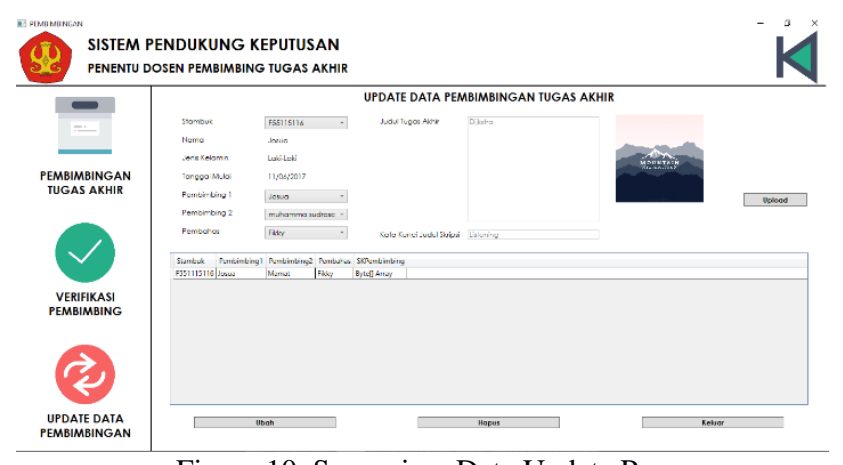

Figure 10. Supervisor Data Update Page

K. Thesis Title Data Update Interface

This page is used to make changes to the title data that is problematic after the proposal examination process is done but cannot be continued and wants to make changes which 
also must state the statement of change in the thesis title. The results of the implementation of the thesis title data update page can be seen in Figure 11.

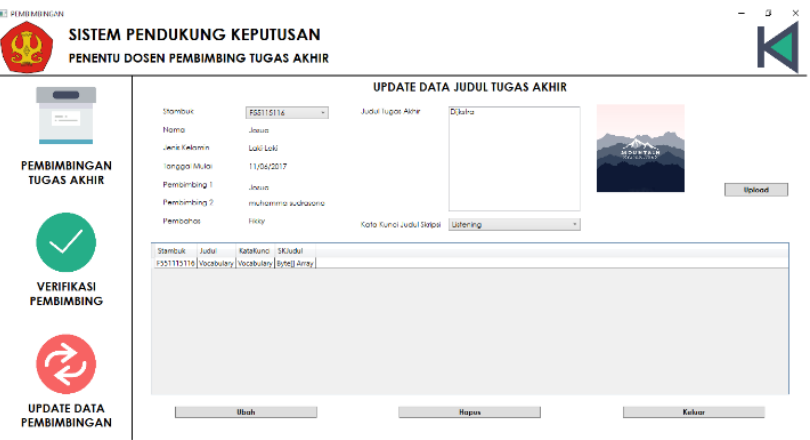

Figure 11. Thesis Title Data Update Page

\section{Judiciary Verification Interface}

This page is used to move the assistance process with status has been completed and can be saved in the recapitulation of the supervisor's report to determine the number of lecturers who act as supervisor in a year. The results of the implementation of the judiciary verification page can be seen in Figure 12.

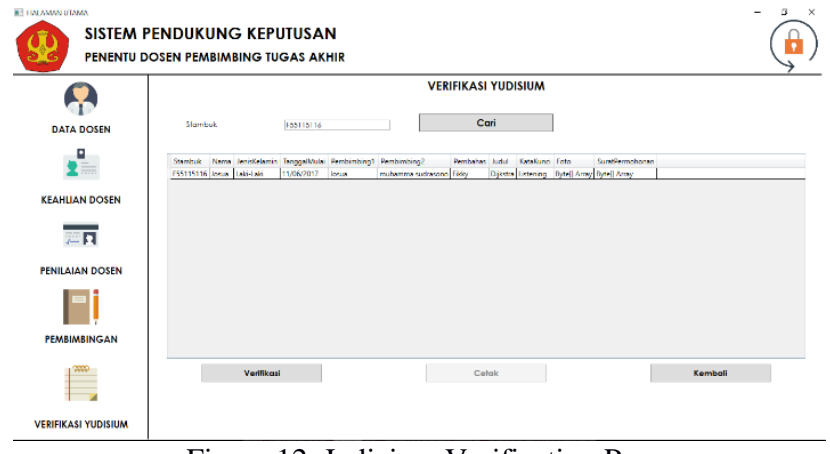

Figure 12. Judiciary Verification Page

\section{CONCLUSION}

Decision Support Systems to determine thesis supervisors in the English Department at Tadulako University can help and facilitate the English Department of Tadulako University in selecting thesis supervisors accurately and quickly with a mathematical calculation system so that the recommendations produced are more accountable.

The author suggests suggestions that can be considered for further development, including decision support systems in determining thesis supervisors can be developed by combining several different decision support system methods. In addition, it is necessary to add more criteria data to be more maximal in determining the ideal thesis supervisor, for example by combining the criteria used in similar studies that have previously been carried out by other researchers or similar research that is a reference source.

\section{REFERENCES}

[1] E. L. Ruskan, "Implementasi Metode AHP Sebagai Alternatif Keputusan Penentuan Pembimbing Tugas Akhir (Studi Kasus pada Jurusan SI Fakultas Ilmu Komputer)," J. Sist. Inf., vol. 7, no. 2, Oct. 2015.

[2] H. A. Cahyono and S. T. H. Thamrin, "Sistem Pendukung Keputusan Penentuan Pembimbing Skripsi Menggunakan Metode Analytical Hierarchy Process," s1, Universitas Muhammadiyah Surakarta, 2016.

[3] A. Asrul khairul Umam, "Sistem Pendukung Keputusan untuk Menentukan Pembimbing Skripsi Berdasarkan Kriteria Bidang Keahlian Dosen dengan Menerapkan Metode Fuzzy (Studi Kasus : Jurusan Teknik Informatika UIN Sunan Gunung Djati Bandung)," diploma, UIN Sunan Gunung Djati Bandung, 2016.

[4] I. Laengge, H. F. Wowor, and M. D. Putro, "Sistem Pendukung Keputusan Dalam Menentukan Dosen Pembimbing Skripsi," J. Tek. Inform., vol. 9, no. 1, Oct. 2016.

[5] I. Septiana, M. Irfan, A. R. Atmadja, and B. Subaeki, "Sistem Pendukung Keputusan Penentu Dosen Penguji Dan Pembimbing Tugas Akhir Menggunakan Fuzzy Multiple Attribute Decision Making dengan Simple Additive Weighting (Studi Kasus: Jurusan Teknik Informatika UIN SGD Bandung)," J. Online Inform., vol. 1, no. 1, pp. 4350, Jun. 2016

[6] M. Muslihudin and R. F. Andriyanti, "Implementasi Metode Weighted Product Menentukan Beasiswa Bidik Misi Stmik Pringsewu," J. Tek. Inform. DAN Sist. Inf., vol. 4, no. 2, pp. 156-163, Mar. 2018.

[7] A. Manzilati, Metodologi Penelitian Kualitatif: Paradigma, Metode, dan Aplikasi. Universitas Brawijaya Press, 2017.

[8] S. Rahardjo and Gudnanto, Pemahaman Individu Teknik Nontes. Kencana, 2011.

[9] A. M. Yusuf, Metode Penelitian Kuantitatif, Kualitatif \& Penelitian Gabungan. Prenada Media, 2016.

[10] F. Sari, Metode dalam Pengambilan Keputusan. Deepublish, 2018.

[11] D. Nofriansyah, Konsep Data Mining Vs Sistem Pendukung Keputusan. Deepublish, 2015. 